\title{
DO ONGOING NETWORKS BLOCK OUT NEW FRIENDS? RECONCILING THE EMBEDDEDNESS CONSTRAINT DILEMMA ON NEW ALLIANCE PARTNER ADDITION
}

\begin{abstract}
Research Summary: This study addresses a theoretical dilemma regarding how alliance network constraint (reflected by network cohesion) affects a firm's alliance formation with new partners. Using a network pluralism approach, we separate a firm's ego alliance network into two activitybased networks - an exploratory network and an exploitative network - based on the primary value chain activity involved in each alliance. We argue that the cohesion of exploratory or exploitative networks has an inverted U-shaped effect on the addition of new partners in the same activity-based network, and a positive effect on the addition of new partners in the other network. Results based on data from the biotechnology industry largely support our predictions with one exception. Our study contributes to both scholarly understanding of network embeddedness and alliance practice.

Managerial Summary: The structure of firms' ongoing alliance networks may have paradoxical implications for their efforts to search for and form alliance with new partners. That is, when a firm's alliance partners are tightly connected with each other, the cohesive network tends to both encourage and impede the focal firm to add new partners. We resolve this dilemma by showing that when a firm is deeply entrenched in a cohesive alliance network conducting a certain type of activities (e.g., R\&D activities), it may not easily add new R\&D alliance partners. However, it may still be able to escape from the cohesive $R \& D$ alliance network by seeking new partners conducting other activities (e.g., manufacturing activities).
\end{abstract}

Keywords: addition of new alliance partners, network embeddedness, network pluralism, network cohesion, alliance network 


\section{INTRODUCTION}

Firms are often embedded in and constrained by their alliance networks (Carpenter, Li, and Jiang, 2012; Provan, Fish, and Sydow, 2007). This embeddedness provides a dilemma for firms that seek to add new partners, which refers to partners that have neither had a direct prior alliance with the focal firm nor a prior alliance with the focal firm’s existing partners. On the one hand, adding new partners can redefine the composition and pattern of interconnection in a firm’s alliance portfolio and introduce alternative external support (Beckman, Haunschild, and Phillips, 2004), thus helping counteract the constraints exerted by an ongoing alliance network (Gargiulo, 1993; Walker, Kogut, and Shan, 1997). On the other hand, the effort to add new partners per se may also be constrained by the embeddedness in ongoing alliance networks. For example, the structural path dependence on existing alliances may compel firms to form new alliances with existing partners or the partners of partners (Gulati and Gargiulo, 1999; Snijders, van de Bunt, and Steglich, 2010), impeding the firms from seeking new partners (Gargiulo and Benassi, 2000; Lin, Yang, and Demirkan, 2007). Taken together, the embeddedness constraints from an alliance network can both encourage and hamper the addition of new partners.

This dilemma leads to the following question: To what extent can firms offset alliance network constraints by adding new partners given that doing so is also confined by network constraints? In this study, we capture network constraints with network cohesion, which refers to the intensity of mutual commitment and interdependencies between a firm and its alliance partners (Ahuja, 2000; Burt, 1992), and depicts the firm’s embeddedness in its current alliance network (Bae and Gargiulo, 2004). Reflecting the dilemma above, a cohesive alliance network can both motivate the focal firm to seek new partners as it strives to reduce constraints and increase autonomy, and, at the same time, impede it from doing so. 
We reconcile this dilemma by adopting a network pluralism approach. Network pluralism highlights the fact that actors are simultaneously embedded in multiple networks consisting of relationships that are defined by different activities (Gould, 1991; Laumann, 1973). These parallel activity-based networks may respectively exert embeddedness constraints on the focal actors. In addition, actors who simultaneously participate in multiple networks can manage the embeddedness constraints from one network by altering the same network or by shaping another parallel network (Benson, 1975; Lomi and Pattison, 2006). As such, the network pluralism approach allows us to better understand the embeddedness constraints from different networks and the distinct strategies through which actors can manage these constraints.

Following the logic of network pluralism, we specify different alliance networks based on their primary activities. Prior research has classified alliances into two categories in terms of the primary value chain activities involved (Koza and Lewin, 1999; Rothaermel and Deeds, 2004): exploratory alliances aiming at discovering new knowledge through research activities; and exploitative alliances aiming at leveraging existing knowledge through manufacturing- or market-related activities. Using this activity-based categorization, we separate a firm's alliance portfolio into two networks, i.e., an exploratory network involving knowledge discovering activities (e.g., fundamental research, $\mathrm{R} \& \mathrm{D}$ ), and an exploitative network involving commercialization activities (e.g., logistics, production, marketing, etc.).

We argue that simultaneously participating in these two activity-based networks, firms can counteract constraints arising from a cohesive exploratory (exploitative) network by adding new partners in that network or in the other network. However, when the constraints from either network become very strong, they will hamper the addition of new partners to that network - a phenomenon that we call a within-network effect. In contrast, constraints in the exploratory (exploitative) network can encourage, rather than limit, the addition of new partners in the 
exploitative (exploratory) network - a phenomenon that we call a between-network effect. In other words, network constraints mainly confine the addition of new partners within the same activity-based network, but not across alliance networks constructed for different activities.

Our study makes two main contributions. First, we adopt the network pluralism approach to advance the alliance network literature. By separating a firm's alliances into an exploratory network and an exploitative network, we show that firms have distinct ways to manage alliance networks involving different activities, highlighting the value of the network pluralism approach in examining firms' alliance network management (Provan et al., 2007; Wassmer, 2010; Zaheer, Gözübüyük, and Milanov, 2010).

Second, we contribute to the network embeddedness perspective by resolving the embeddedness dilemma on new alliance partner addition. By differentiating firms' exploratory and exploitative networks, we show the differences between the within- and between-network effects of embeddedness constraints on new partner addition. As such, we explore the interplay and mutual effects between embeddedness forces from different networks, depicting new ways of examining network embeddedness (Carpenter et al., 2012; Shipilov et al., 2014).

\section{THEORETICAL BACKGROUND}

\section{Network pluralism: Interplay between multiple sources of network embeddedness}

The network pluralism approach emphasizes the fact that actors can be embedded in multiple networks consisting of different forms of social ties (Connolly, 2005; Laumann et al., 1978). Commonly assuming multiple roles and engaging in different activities, actors often develop various types of social ties, and therefore form multiple parallel networks conducting different activities (Halinen and Jan-Åke., 2005; Laumann, Marsden, and Prensky, 1989). Given the distinct natures of these activities, these networks tend to be formed with different pools of actors and characterized by different patterns of interaction and distinct relational and structural 
configurations (Laumann et al., 1978). For example, an employee can engage in both informal, personalized contacts and formal, task-based interactions with potentially different groups of colleagues in the workplace, thus developing a friendship network and a task network that have potentially distinct contents and/or structural features (Toegel, Kilduff, and Anand, 2013).

Through the network embeddedness perspective (Granovetter, 1985; Uzzi, 1997), which highlights the contextual impacts exerted by a network on its participants, the network pluralism approach provides a novel lens to examine firms' embeddedness constraints in alliance networks. It is noted that an alliance network, while supporting participant firms' operations, also exerts embeddedness constraints on the firms' decisions and actions (e.g., Bae and Gargiulo, 2004; Gargiulo and Benassi, 2000). On the one hand, the development and operation of an alliance network are characterized by structural path dependence (Gulati and Gargiulo, 1999; Snijders et al., 2010; Watts, 1999), such that firms' interactions with alliance partners are both determined by the resource commitments they have made in ongoing alliances and shaped by the relational norms and structural features formed through previous interactions in the alliance network (Gulati, 1999). On the other hand, since firms depend on their partners to secure otherwise inaccessible value in the alliance network (Zajac and Olsen, 1993), the partners thus have the power to at least partially impact the focal firms’ actions (Yan and Gray, 2001).

Commonly conducting different types of collaborative activities, firms usually participate in multiple different activity-based alliance networks simultaneously. For example, a venture capital (VC) firm may participate in both a syndicate network with other VC firms and an investment network with target ventures (Hsu, 2004; Sorenson and Stuart, 2008). Given the distinct natures of these collaborative activities, these activity-based alliance networks may involve different pools of partners, demand different relational and structural configurations, and require different resource commitments, leading to their distinct features of structural path 
dependence and interdependence among partners (Walker et al., 1997; Watts, 1999). As a result, these alliance networks tend to respectively exert potentially distinct embeddedness influences on the focal firms, constraining their actions in different ways (Granovetter, 1985).

Notably, such heterogeneous embeddedness forces may jointly impact firms’ actions and thus allow constraint-offsetting strategies across their different alliance networks. For example, it has been noted that a firm can be motivated to form alliances to diversify into a new business domain so as to alleviate the pressure and countervail the constraints from the alliance networks in its existing business domains (Kim, Hoskisson, and Wan, 2004; Saxton, 1997). As such, highlighting the parallel embeddedness constraints from different activity-based alliance networks can provide new perspectives to understand firms’ embeddedness constraint-offsetting strategies, enriching the traditional approach that unifies all alliances into a single network (Gould, 1991). In this study, we highlight a dilemma of embeddedness constraint in affecting the addition of new partners, and use the above network pluralism approach to resolve the dilemma.

\section{Embeddedness constraint and the addition of new alliance partners: A dilemma}

It has been recognized that firms are motivated to take actions to manage their alliance networks to absorb or offset the embeddedness constraints arising from these alliance networks (Burt, 1980; Emerson, 1962; Gargiulo, 1993). A prevalent instance of such constraint-offsetting efforts is to add new partners that are previously unconnected with the firm and its direct contacts (Borgatti and Foster, 2003; Kogut, Shan, and Walker, 1992). These new and previously unconnected partners may bring alternative resources to the focal firms’ alliance network and alter the contents and configurations of their interactions with existing partners (Borgatti, 2010; Gimeno, 2004), thus helping lower the constraints exerted by the relational and structural embeddedness in the current alliance network (Carpenter et al., 2012; Walker et al., 1997). As such, alliance network constraints, as they strengthen, tend to motivate firms to add new partners. 
However, firms' attempts to add new partners may themselves be confined by current embeddedness constraints (Burt, 2000; Granovetter, 1985). As discussed, the development of alliance networks is constrained by ongoing structural path dependence and interdependence (Carpenter et al., 2012). For example, driven by the resource commitments and normative codes they have accumulated with existing partners, firms are motivated to reproduce ongoing alliances (Gulati and Gargiulo, 1999). Likewise, information acquired through existing alliances tends to direct firms to existing partners or their contacts rather than to new partners isolated from the ongoing network (Burt, 1992). These embeddedness effects will lead firms to form alliances with existing partners or the partners of existing partners, keeping the firms from adding new partners given the limited resources (time, attention, personnel, etc.) devoted to alliance management (Das and Teng, 1999; Lin et al., 2007). Taken together, by simultaneously motivating firms to add new partners and hampering them from doing so, the embeddedness constraints in ongoing alliance networks present an interesting dilemma for firms' efforts to add new partners.

\section{Resolving the dilemma: A network pluralism approach}

We draw on the network pluralism approach to address this dilemma. As discussed, the embeddedness constraint in a network can not only be managed by altering that network, but can also be countervailed through altering other networks (Lomi and Pattison, 2006). For example, a firm can resolve the pressure from its economic exchange network by strengthening its political network (Benson, 1975; Xin and Pearce, 1996). Likewise, a firm’s board interlock network can help coordinate the operations in its alliance network (Gulati and Westphal, 1999; Zajac, 1988). In such a manner, the coexistence of multiple alliance networks based on different activities can diversify a firm's options to manage the embeddedness constraints from those networks. That is, when a firm is constrained by a highly cohesive alliance network that conducts a particular type 
of activities, the focal firm can countervail the embeddedness constraints by adding new partners either in this network or in other alliance networks conducting different activities.

In this study, we highlight the distinction between two activity-based networks, i.e., the exploratory network and the exploitative network. Prior studies have classified alliances into exploratory alliances and exploitative alliances (Hoehn-Weiss and Karim, 2013; Rothaermel and Deeds, 2004). We posit that this categorization, which has been mainly applied to classify dyadic alliances, also has particular implications at the network level and can distinguish the two activity-based networks for the following reasons.

First, despite the heterogeneity among the specific tasks and activities involved in different exploratory (exploitative) alliances, all exploratory (exploitative) alliances serve similar strategic objectives, i.e., creating new knowledge (profiting from existing knowledge). As such, firms often strategically balance and coordinate all their exploratory (exploitative) activities, systematically planning the formation and development of all exploratory (exploitative) alliances to achieve the overarching strategic objectives (Hoffmann, 2007; Reuer and Zollo, 2005). For example, although firms’ exploratory alliances around different product lines involve different R\&D activities with potentially different partners, it is necessary and common for the firms to coordinate the portfolio of exploratory alliances so as to reduce potential cannibalization between different products and enhance overall exploratory effectiveness (Argyres and Silverman, 2004; Hill and Rothaermel, 2003). As such, the evolution of each exploratory (exploitative) alliance is not isolated, but rather interconnected to the other (Lavie and Rosenkopf, 2006).

Moreover, a firm’s exploratory (exploitative) alliance partners, conducting similar or comparable business activities, may themselves interact and collaborate with each other through the referral of the focal firm (Burt, 1992; Gulati, 2007). For example, independent laboratories allying with the same set of pharmaceutical firms may establish research collaborations among 
themselves (Powell, 1998; Powell, Koput, and Smith-Doerr, 1996). Likewise, firms may actively coordinate the relationships between their major suppliers in order to enhance the effectiveness of their supply chain management (Lambert and Cooper, 2000; Rushton, Croucher, and Baker, 2014). Such coordination across partners in alliances involving the same type of collaborative activities can further foster the interplay between parallel exploratory (exploitative) alliances.

Taken together, different exploratory (exploitative) alliances connect and coevolve with each other. Such interconnection and coevolution among relationships across different participants is a central feature of social networks (Carpenter et al., 2012; Scott, 2000). In this regard, following the network pluralism approach, it is reasonable to integrate a firm's alliances into two activity-based alliance networks - an exploratory network and an exploitative network.

Carrying different types of collaborative activities, exploratory and exploitative alliance networks tend to constrain firms in distinct ways. That is, the distinct strategic motives of exploratory and exploitative alliances tend to require firms to shape their interactions with and investments to exploratory and exploitative partners in different ways (Reuer and Ariño, 2007; Tiwana, 2008). For example, flexible governance mechanisms and asset arrangements are generally favored in exploratory alliances to facilitate the creation of novel knowledge, while formalized contracts and high specific investments are preferable in exploitative alliances to reduce transaction costs and enhance efficiency (Hoetker and Mellewigt, 2009).

As a result, firms tend to construct the partner portfolios and network structures of their exploratory and exploitative alliances in distinct ways (Lavie, 2006). For instance, when a firm has a long history as a manufacturing outsourcer and recently starts independent R\&D activities, it may be constrained by a highly cohesive exploitative network but also have high autonomy in its sparse exploration network. In contrast, a research institute may have a cohesive exploratory network to support its research activities but only a small and loosely connected exploitative 
network for trial manufacturing (see Appendix 1 for illustration). As such, firms tend to encounter distinct patterns of structural path dependence in exploratory and exploitative networks. By the same token, firms may depend on their exploratory and exploitative alliance partners in distinct ways (Lavie and Rosenkopf, 2006). For example, partners in exploitative alliances may rely more heavily on each other's complementary assets than those in exploratory alliances (Rothaermel, 2001, 2001). Taken together, a firm’s exploratory and exploitative alliance networks tend to exert distinct embeddedness constraints, which would allow the focal firm to manage such constraints both within the same network and across different networks.

Following this logic, we develop hypotheses below to resolve the constraint dilemma by examining the interplay between the exploratory and exploitative networks. We emphasize a central structural feature, i.e., network cohesion, to capture the embeddedness constraints in a firm’s ongoing alliance networks (Burt, 1992; Coleman, 1988). We will unveil the different effects of alliance network cohesion on the addition of new partners within the same network and across different networks, highlighting the value of the network pluralism approach.

\section{HYPOTHESIS DEVELOPMENT}

\section{Within-network effects of alliance network cohesion}

Network cohesion depicts the extent to which an actor's ego network involves alters who are themselves closely linked (Burt, 1997). When a firm’s alliance network is highly cohesive, its collaboration and accessible external resources are confined to a group of tightly connected partners (Yu, Subramaniam, and Cannella, 2013). Such tight links among partners indicates high mutual commitment and intensive interactions, thus fostering strong structural path dependence and collective norms (Beckman and Burton, 2008). On the other hand, the focused collaboration and resource exchange in a cohesive alliance network indicates that the focal firm depends on a group of close-knit partners (Yu, Gilbert, and Oviatt, 2011), allowing these partners to influence 
the focal firm's decisions and actions. Therefore, high cohesion in a firm’s alliance network indicates strong embeddedness constraints (Gargiulo and Benassi, 2000).

The constraint from a cohesive exploratory (exploitative) network may motivate a firm to add new partners conducting the same type of alliance activities. That is, by forming exploratory (exploitative) alliances with firms that are not currently participating in the focal firm's alliance network, the firm can loosen the close-knit links among its existing partners, thus reducing the cohesion of the ongoing exploratory (exploitative) network and mitigating its embeddedness constraint (Gnyawali and Madhavan, 2001; Mizruchi, 1993). For example, adding new partners can create potential brokerage opportunities between the newly added partners and existing ones, thus increasing the focal firm’s structural autonomy (Burkhardt and Brass, 1990; Burt, 1992).

Adding new partners in the same network can also help lower the firm's reliance on existing partners (Gimeno, 2004). Adding new exploratory partners can help the focal firm secure alternative sources of external knowledge, providing more diversified solutions for creating new knowledge (McFadyen and Cannella, 2016). Likewise, adding new exploitative partners can diversify the focal firm's choices in leveraging existing knowledge, reducing the relative importance of existing exploitative partners (Hart and Saunders, 1997; Pfeffer and Salancik, 1978). As such, adding new partners allows the focal firm to mitigate some dependence constraints arising from its ongoing network (Bae and Gargiulo, 2004; Xia, 2011; Yan and Gray, 1994). Taken together, adding new exploratory (exploitative) partners can countervail embeddedness constraints from a cohesive exploratory (exploitative) network. Accordingly, as the cohesion in its exploratory (exploitative) network increases, the firm will be more motivated to add new exploratory (exploitative) partners to offset the enhanced constraints.

Nonetheless, a highly cohesive exploratory (exploitative) network can also confine the addition of new alliance partners to that network. First, the dense and close-knit contacts across 
the partners in the same activity-based alliance network can foster an atmosphere of mutual trust and commitment (Ahuja, 2000; Rowley et al., 2005), facilitating effective coordination and resource sharing among existing partners. As such, a highly cohesive exploratory (exploitative) network increases the opportunity cost of adding new and unfamiliar exploratory (exploitative) partners. Moreover, a cohesive exploratory (exploitative) network indicates high resources and interactions committed to the existing exploratory (exploitative) partners, thus locking the focal firm's alliance development efforts in existing partnerships and preempting the addition of new partners conducting the same type of alliance activities (Bae and Gargiulo, 2004; Beckman and Burton, 2008). In addition, the firm’s sources of information in a highly cohesive alliance network tend to be relatively redundant (Burt, 1992), impeding its search for new partners.

In sum, we posit a non-monotonic relationship (inverted U-shaped) between the cohesion of a firm’s exploratory (exploitative) alliance network and the addition of new partners in the same activity-based alliance network. That is, when an activity-based alliance network is of very low cohesion, the focal firm would have limited need to countervail the low embeddedness constraints from this network by adding new partners in the same network even though the firm has high discretion to do so (Provan, 1980). As cohesion increases, the firm's need to offset its embeddedness constraints grows. In this situation, although constraint in the ongoing network also increases, its effect may not be strong enough to keep the focal firm from seeking out new partners. As such, the firm's addition of new partners in this alliance network will at first increase along with the increasing cohesion. However, when the cohesion becomes very high, it may act as an iron cage that impedes the firm from adding new partners conducting the same type of alliance activities. As such, even though the extremely high cohesion of an activity-based network motivates the firm to add new partners to this network, such cohesion provides little 
autonomy and few opportunities to do so. Taken together, the addition of new partners in the same activity-based network tends to be highest at moderate levels of cohesion. Stated formally:

Hypothesis 1: The cohesion of a firm's exploratory network has an inverted-U shaped relationship with the addition of new exploratory alliance partners.

Hypothesis 2: The cohesion of a firm's exploitative network has an inverted U-shaped relationship with the addition of new exploitative alliance partners.

\section{Between-network effects of alliance network cohesion}

Through the network pluralism perspective, simultaneously participating in multiple networks allows an actor to offset the embeddedness constraints across these parallel networks. For example, a firm may both cooperate and compete with other firms and thus maintain both a cooperative and a competitive network. In this case, the firm can leverage its cooperative networks to mitigate the competitive pressure and manage its competitive ties and networks (Gimeno, 2004; Tsai, 2001). Following this logic, we posit that by simultaneously participating in exploratory and exploitative alliance networks, firms can offset the embeddedness constraints derived from the exploratory network by adding new exploitative partners, and vice versa.

Specifically, adding previously unconnected exploratory (exploitative) partners can put a firm in brokerage positions between these new partners and its existing exploitative (exploratory) partners (Burt, 1992). Such brokerage positions across the two alliance networks can facilitate the firm to offset the embeddedness constraint from either existing network. That is, the new exploratory (exploitative) partners may possess non-redundant information and interfirm ties (Ahuja, 2000; Burt, 2000), providing opportunities for the focal firm to identify and develop new exploitative (exploratory) partners. The focal firm may also benefit from bridging the existing exploitative (exploratory) partners and the new exploratory (exploitative) partners, who may possess complementary knowledge and resources (Burt, 1997; Zaheer and Soda, 2009). Taken together, such brokerage opportunities created by adding new exploratory (exploitative) partners 
can increase the firm's power and autonomy in its existing exploitative (exploratory) network, thus helping alleviate the embeddedness constraint from the network.

Moreover, exploratory and exploitative activities can create synergistic effects between each other over time (Tushman and O'Reilly, 1996). That is, firms can apply the new knowledge created through exploratory activities in one period with new exploitative activities in the next. Meanwhile, the ongoing exploitative activities may help the firm identify the need and direction of future exploratory activities. As such, the ongoing exploratory (exploitative) network may create motives and opportunities for the firms to add new exploitative (exploratory) partners (Benner and Tushman, 2003; Gupta, Smith, and Shalley, 2006). For example, by working with ongoing exploratory partners to create novel knowledge, a firm can be motivated to search for new exploitative partners to effectively implement and leverage the new knowledge (Rothaermel and Deeds, 2004). Likewise, new information emerging from the collaborative experiences with current exploitative partners (new technique issues, new market information, etc.) may point out promising directions for future research, thus inspiring the firms to search for new exploratory alliance partners (Doz, Olk, and Ring, 2000; Ruekert and Walker, 1987).

In sum, the constraints from cohesive exploratory (exploitative) networks will encourage firms to add new exploitative (exploratory) alliance partners. For the following reasons, we argue that such between-network effects of network cohesion are monotonically positive, as opposed to the non-monotonic within-network effects of network cohesion.

First, as discussed, a cohesive alliance network may preempt the addition of new partners by locking the focal firm’s limited collaborative resource commitments within its ongoing alliance partners (Lin et al., 2007). However, firms may avoid such constraints generated from one activity-based alliance network when seeking new partners conducting the other type of activities. Exploratory and exploitative alliances, as noted above, tend to require different 
resources commitments (Koza and Lewin, 1999). As such, high cohesion in one alliance network may not necessarily preempt the addition of new partners in the other due to the different requirements for resource and capability input in these two activity-based networks.

Second, the distinct nature of exploratory and exploitative activities also determines that exploratory and exploitative alliances have non-substitutable functions (Koza and Lewin, 1998). Instead, as discussed above, adding new exploratory (exploitative) partners may complement the function of existing exploitative (exploratory) alliances. As such, adding new exploratory partners may not undermine the importance of the existing exploitative network (and vice versa), thus reducing the potential tension between adding new partners and maintaining existing ones.

In addition, a firm will potentially have distinct ongoing partner portfolios and potential partner pools respectively for its exploratory and exploitative alliance networks (Lavie, Kang, and Rosenkopf, 2009). For example, research institutes mainly engage in exploratory alliances, while marketing agencies mainly form exploitative alliances. Therefore, it is reasonable to expect that the mutual familiarity and commitment across tightly connected exploratory (exploitative) partners may not constrain the expansion of the exploitative (exploratory) network, which conducts a different type of collaborative activities with potentially different groups of partners.

Taken together, we propose the following monotonic relationships between the network cohesion of one activity-based network and the addition of new partners in the other.

Hypothesis 3: The cohesion of a firm's exploitative network has a positive relationship with the addition of new exploratory alliance partners.

Hypothesis 4: The cohesion of a firm's exploratory network has a positive relationship with the addition of new exploitative alliance partners. 


\section{METHOD}

\section{Sample}

To test our hypotheses, we used the biotechnology industry as our empirical setting (indicated by SIC code 2836). This industry provides a good sample space because it is characterized by high alliance frequency (Baum and Silverman, 2004; Gay and Dousset, 2005; Hagedoorn, 1993). Moreover, as a knowledge-intensive industry, it features frequent innovations and strong motives to commercialize those innovations (Rothaermel and Deeds, 2004), requiring member firms to simultaneously engage in intensive exploratory and exploitative activities.

Using the Securities Data Corporation (SDC) database on Joint Ventures and Alliances, as well as BioScan and Recombinant Capital (Recap) databases, we collected information about all alliances formed in the biotechnology industry from 1996 to 2010. The SDC database includes information on all forms of alliances and is compiled from various information sources (industry and trade journals, newspapers, Securities and Exchange Commission (SEC) filings, etc.). The BioScan database is constructed by American Health Consultants, and provides a comprehensive directory of information covering firms in the biotechnology industry all over the world (Powell et al., 1996; Rothaermel and Deeds, 2004). Similarly, the Recap database is managed by Recombinant Capital, a consulting firm specializing in the biotechnology industry and reporting data on biotechnology alliances from press releases, SEC filings, and company presentations made at public meetings. As a number of authors have noted, SDC, BioScan, and Recap are among the few comprehensive information sources that can support large-scale empirical research on alliance networks (Adegbesan and Higgins, 2011; Anand and Khanna, 2000; Rothaermel and Boeker, 2008; Sampson, 2007; Schilling and Phelps, 2007).

From the three data sources, we extracted information about 3,635 alliances announced by biotechnology firms during the 15-year observation window. These alliances involved 479 
organizations in total and this set of alliances comprised the "whole network" from which information was extracted for ego-network analyses. The 479 organizations involved in the whole network are quite heterogeneous, including large, publicly listed firms, small private firms, non-US firms, and not-for-profit organizations such as hospitals, labs, universities, and research institutes. Because our theory is about organizations that engage in both exploration and exploitation, we limited our sample to pharmaceutical companies for which we could identify firm age, firm size, and firm performance (i.e., three control variables explained below). This left us with a sample of 168 firms that formed the foundation for our ego-network analyses.

To construct our dataset, we organized the original alliance information from the three data sources as follows. We initially identified all active alliances every year and constructed a series of binary adjacency matrices to record the ongoing alliances in each year. Because alliance termination dates were not available for many sample alliances, we followed prior studies based on the same data sources (Gilsing and Nooteboom, 2005; Gulati and Gargiulo, 1999) and assumed a 5-year duration for alliances without exact termination dates. The duration of all alliances with exact termination dates averaged 4.57 years, lending support to the assumption of 5-year duration. Moreover, it has been widely noted that fully achieving the potential of alliances may take time, since the partner firms have to first invest in and coordinate their cooperation with partners, as well as internalize the knowledge they learn or the resources they access through alliances into their own routines and resource bases (Gulati, 1995; Stuart, 2000).

To capture the change of a firm's alliance networks, we followed the convention of existing alliance network studies and created five-year moving windows, predicting a firm’s renewal of existing partners and addition of new ones in year $\mathrm{t}+1$ with its alliance networks from year t to t-4 (Bae and Gargiulo, 2004; Stuart, 2000). As such, our sample started in 2001, with the alliance activity information from 1996 to 2000 as a baseline in the first 5-year moving 
window. Also, only firms that appear in the industrial alliance network at least once from year t4 to $t$ were included as our observations in year t. Through this sampling procedure, we identified 1,025 observations from the 168 sample firms from 2001 to 2010.

Using UCINET, the network analytic package, we constructed two alliance networks for the whole industry for each year (one exploratory network and one exploitative network), from which the information on each firm's ego networks could be extracted. Following prior studies (Gay and Dousset, 2005; Koza and Lewin, 1998; Rothaermel and Deeds, 2004), we identified exploratory and exploitative alliances through the stated activities of each alliance, designating alliances covering exploratory activities of the industrial value chain (basic research, drug discovery, and development, etc.) as exploratory alliances, and alliances focusing on exploitative activities (regulatory processes, manufacturing, marketing and sales, and service, etc.) as exploitative alliances. Importantly, prior research has noted that many alliances formed in the biotechnology industry are ambidextrous alliances, which involve both exploratory and exploitative activities (Gay and Dousset, 2005; Rothaermel and Alexandre, 2009). The composition of our dataset confirms this finding. The proportion of ambidextrous alliances in each sample firm's alliance set ranged from $18 \%$ to $69 \%$, with larger firms tending to have relatively smaller proportions of ambidextrous alliances due to the larger number of alliances they have. In general, about $43 \%$ of the alliances formed by our sample firms are ambidextrous. The relatively high prevalence of ambidextrous alliances formed by our sample firms leads to overlap between exploratory and exploitative networks. However, the two activity-based networks in the biotechnology industry demonstrated significant distinctions between them. First, over our 15-year observation window, we identified 479 organizations that participated in the entire alliance network developed by our sample firms (including the 168 firms themselves). Among the 479 organizations, 187 participated in both exploratory and exploitative alliances 
over time, 212 exclusively participated in exploratory alliances, and 80 exclusively participated in exploitative alliances. In this regard, over time, alliances conducting different activities led to two distinct pools of partners (i.e., 392 exploratory partners and 267 exploitative partners), with an overlap between them of 38\%. Moreover, the two alliance networks in the industry demonstrated distinct structural features over time. That is, the overall tie strength (measured by both asset investments and duration of the alliances) and density of the exploratory alliance network were consistently higher than those of the exploitative network over our 15-year observation window (see Appendix 1 for an example, which depicts the different configurations of the two alliance networks across the entire biotechnology industry from 1996 to 2000). In sum, these findings show significant differences between the exploratory and exploitative networks, bolstering our network pluralism approach.

Following prior studies (e.g., Gay and Dousset, 2005; Tiwana, 2008), we included ambidextrous alliances in both exploratory and exploitative alliance networks. Since our conceptualization focuses on exploration and exploitation as distinct activities, regardless of whether these activities are conducted by the same partner or different partners, this approach allows us to capture the completeness of each activity-based network. In order to further confirm the robustness of this method, we conducted two sensitivity analyses using different ways to treat ambidextrous alliances. First, we redefined the exploratory and exploitative alliance networks by randomly classifying each ambidextrous alliance as either exploratory or exploitative. Second, we excluded all ambidextrous alliances from our calculation and constructed the two networks with only non-ambidextrous alliances. The results from these alternative approaches are qualitatively the same as those reported here, as we will discuss below. 


\section{Measures}

The addition of new partners between Time $t$ and Time $t+1$. Our dependent variable, the addition of new exploratory (exploitative) partners was evaluated as the number of a firm’s exploratory (exploitative) partners at Time $t+1$ that were in neither its exploratory alliance network nor its exploitative network at any time before.

Alliance network cohesion at Time t. Network cohesion captures the extent to which an actor's connections are redundant and can be substituted by other third-party ties (Wasserman and Faust, 1994). Following prior studies (Gargiulo and Benassi, 2000; Reagans and McEvily, 2003), we used Burt's network constraint measure to capture the cohesion of each firm’s exploratory and exploitative alliance networks, respectively (c.f., Burt, 1992: 50-71). Specifically, for the focal firm $i$, the cohesion of its exploratory/exploitative network, $C_{i}$, is:

$$
C_{i}=\sum_{i \neq j}\left(p_{i j}+\sum_{i \neq k, k \neq j} p_{i k} p_{k j}\right)^{2}
$$

where $p_{i j}$ denotes the proportion of the total strength of the alliances that ego firm $i$ devotes to a given alter firm $j$ in proportion to the sum of relational strengths of all other of ego firm's alter ties ( $0=$ no alliance, $1=$ non-asset alliances, $2=$ asset alliances/joint ventures), and $\sum p_{i k} p_{k j}$ captures the degree of triadic closure between $i, j$, and third parties $k$ (Reagans, Zuckerman, and McEvily, 2004). Together, this indicator of network cohesion is, in turn, a function of the direct connection between $i$ and $j$ and of the extent to which $j$ connects with other partners $k$ in $i$ 's exploratory or exploitative network. Since we proposed curvilinear relationship between the cohesions of both exploratory (exploitative) alliance networks and the addition of new exploratory (exploitative) partners, we also calculated the cohesion-squared terms for both networks, respectively.

We controlled for a number of factors that may affect our proposed relationships. Following prior studies (e.g., Rothaermel and Deeds, 2004), we controlled for a firm’s 
exploratory and exploitative performance at Time t, which may potentially influence the relationships between alliance network cohesion at Time $t$ and the addition of new partners between Time $\mathrm{t}$ and Time $\mathrm{t}+1$. We used a firm's products in development, a count of the firm's biotechnology products that have entered clinical trials but not reached the pharmaceutical market at the last year in Time t, as the indicator of its exploratory performance. Likewise, we used its products on the market, a count variable of the firm's products that were successfully placed on the market as of the last year in Time t, to capture its exploitative performance.

Prior work has shown that status in the industry affects firm-level network dynamics (Shipilov and Li, 2012; Zaheer and Soda, 2009). High-status firms with more ongoing contacts in the industry are more likely to develop new ties with peripheral firms and potentially reduce their network cohesion over time. Following this notion, we adopted three control variables—a firm’s degree centrality in the entire biotechnology industry alliance network, its firm size, and its financial performance- to control for effects of organizational status and ongoing network size. Degree centrality was computed as the total number of exploratory or exploitative ties (alliances) a firm is engaged in at Time t, with each ongoing alliance counted only once. Firm size was measured by a firm's assets averaged across the five prior years. A firm’s financial performance was measured by its return on assets (ROA) averaged across five prior years.

We also controlled for firm age, as older firms tend to have more products in development and more products on the market (e.g., McFadyen and Cannella, 2010; Sørensen and Stuart, 2000). Following prior studies (Rothaermel and Deeds, 2004; Shan, Walker, and Kogut, 1994), we also controlled for firms' technological diversity, which was measured by a count variable of the biotechnology subfields a firm participates in. In addition, we accounted for sample firms' acquisition efforts, which are another common strategy used by firms in response 
to external constraints (Davis and Cobb, 2010; Hillman, Withers, and Collins, 2009), by controlling for the number of each firm's acquisition deals over each 5-year moving window.

\section{Analytical strategy}

Since our predicted effects are count variables, we used a Poisson estimator to analyze our data. Using the xtpqml command in STATA 14.0, we used robustness-adjusted fixed-effects Poisson regressions to fit our statistical models (Wooldridge, 1999). This approach estimates a quasi-maximum likelihood fixed-effects Poisson estimator with robust standard errors (Simcoe, 2007). The advantage of this approach is that it generates consistent estimates under rather weak assumptions and only the conditional mean needs to be specified, removing the necessity of assuming a specific distribution and enhancing the efficiency of the estimation.

\section{RESULTS}

Table 1 provides descriptive statistics and correlations for all variables. On average, the network cohesion in firms' exploitative networks (mean=0.284) is higher than the cohesion in their exploratory networks (mean=0.095). This is consistent with prior allance network research as exploratory activities benefit more from relatively sparse and diversified network structure, while exploititive activities benefit more from cohesive and close-knit network structures (Ahuja, 2000; Gulati, 1995, 1999). Also, after including all of the control variables, the partial correlation between the addition of exploratory and exploitative partners is positive but insignificant ( $\mathrm{r}=0.033$, n.s.), providing preliminary support to our argument that the addition of new exploratory and exploitative alliance partners is not mutually exclusive.

Insert Tables 1, 2, and 3 about here

Tables 2 and 3 respectively report the addition of new exploratory and exploitative partners. In each table, Model 1 represents the base model that includes only control variables, 
Models 2 and 3 respectively represent the main effects of exploratory and exploitative network cohesion and their squared terms, and Model 4 reports the fully-specified model including all independent predictors. Variance Inflation Factors (VIFs) suggested minimal multicollinearity in any of our models (average VIF=1.24, maximum VIF=3.37). Below, we use the results from Model 4 of each table (the fully specified model) to test our hypothesized relationships.

Hypotheses 1 and 2 predict inverted-U shaped effects of firms’ exploratory (exploitative) network cohesion on the addition of new exploratory (exploitative) partners. Both hypotheses are supported. Model 4 of Table 2 reveals that the cohesion of exploratory network is positively related to the addition of new exploratory partners $(b=1.77, s d=0.25, p=0.00)$, while exploratory cohesion squared has a negative effect $(b=-3.13, \mathrm{sd}=0.83, \mathrm{p}=0.00)$, thus supporting the curvilinear (inverted-U shaped) relationship predicted by Hypothesis 1 (see Figure 1). Likewise, Model 4 of Table 3 shows that the cohesion of firms' exploitative network is positively related to the addition of new exploitative partners $(b=6.18$, $\mathrm{sd}=1.11, \mathrm{p}=0.00)$, and the effect of its squared term is negative $(b=-6.96$, $s d=1.96, p=0.00)$, indicating an inverted- $U$ shaped relationship between exploitative network cohesion and the addition of new exploitative partners and supporting Hypothesis 2 (see Figure 2).

Insert Figures 1, 2, and 3 about here

Hypotheses 3 and 4 predicted the linear between-network effect of network cohesion on the addition of new partners, such that the cohesion of the ongoing exploratory (exploitative) alliance network will monotonically encourage firms to add new exploitative (exploratory) partners. Model 4 of Table 2 reveals that neither the cohesion of firms’ exploitative network $(b=1.19, s d=1.27, p=0.35)$ nor the exploitative cohesion squared $(b=2.10, s d=2.13, p=0.33)$ are significantly related to the addition of new exploratory partners. Therefore, Hypothesis 3 is not 
supported. In contrast, Model 4 of Table 3 shows that the cohesion of the exploratory alliance network is marginally significantly and positively related to the addition of new exploitative partners $(b=0.56, s d=0.28, p=0.05$ ), and the effect of cohesion squared is insignificant $(b=-0.83$, $\mathrm{sd}=0.83$, $\mathrm{p}=0.32$ ), supporting Hypothesis 4 (see Figure 3). These results together indicate that as expected, the cohesion of one activity-based alliance network may not confine firms' discretion in adding new partners in the other.

With regard to significant control variables, Model 4 in Table 2 shows that a firm is more likely to add new exploratory partners when its degree centrality in the industrial exploratory alliance network is high ( $\mathrm{b}=0.03, \mathrm{sd}=0.01, \mathrm{p}=0.01$ ), which indicates more alliance development opportunities, when its technology diversity is low $(b=-0.22$, $s d=0.05, p=0.00)$, and when its acquisition activities are low $(\mathrm{b}=-0.01, \mathrm{sd}=0.01 \mathrm{p}=0.04)$. However, the addition of new exploratory partners is not dependent on firm size $(b=-0.01$, $s d=0.13, p=0.94)$, firm age $(b=-0.01$, $\mathrm{sd}=0.04, \mathrm{p}=0.75$ ), or prior performance (for exploratory performance, $\mathrm{b}=0.05, \mathrm{sd}=0.03, \mathrm{p}=0.09$; for exploitative performance, $\mathrm{b}=0.50, \mathrm{sd}=0.32, \mathrm{p}=0.11$ ). In contrast, according to Model 4 in Table 3, the addition of new exploitative partners is strongly determined by firms' prior performance (for exploratory performance, $b=0.22$, $s d=0.03, p=0.00$; for exploitative performance, $b=1.43$, $s d=0.37, p=0.00$ ). Also, larger firms (for firm size, $b=0.27, s d=0.16$, $\mathrm{p}=0.08$ ) and older firms (for firm age, $\mathrm{b}=0.08$, $\mathrm{sd}=0.04, \mathrm{p}=0.06$ ) are more likely to add new exploitative partners.

\section{Robustness checks}

As discussed above, for our primary analyses we followed prior alliance studies (e.g., Gay and Dousset, 2005; Tiwana, 2008) and double-counted all ambidextrous alliances in both alliance networks. In order to rule out the potential confounding effect of such overlap between the two networks and confirm the robustness of our methodology and findings, we adopted two 
alternative approaches as sensitivity analyses. First, instead of double-counting all ambidextrous alliances, we randomly assigned each ambidextrous alliance as either exploratory or exploitative. Second, we removed all ambidextrous alliances from the two alliance networks. Table 4 reported the results of both sensitivity analyses. Results largely confirmed our main findings, thus showing the high robustness of both our methodology and conclusions.

Insert Table 4 about here

\section{DISCUSSION}

Drawing on the network pluralism approach (Connolly, 2005; Laumann, 1973), we have developed a novel framework to address the dilemma of how the embeddedness constraints in alliance networks impact firms' efforts to add new partners. We focus on two alliance networks in terms of their primary alliance activities (i.e., exploratory activities or exploitative activities). The results show that the cohesion of the alliance network in each activity-based network has an inverted U-shaped effect on the addition of new partners in the same network, but the level of cohesion in a current exploratory alliance network monotonically encourages the firm to add new exploitative partners. These findings have important theoretical and practical implications.

\section{Implications for the network embeddedness perspective}

We contribute to the network literature by using the network pluralism approach to study network embeddedness effects (Granovetter, 1985; Uzzi, 1997). The network embeddedness perspective posits that actors' decisions are subject to the contextual constraints exerted by the ongoing social ties and networks in which they participate. On the one hand, actors may rely on network partners for valuable support and resources, thus allowing these partners to affect their decisions and actions (Pfeffer and Salancik, 1978). On the other hand, social networks may constrain participants through social norms and structural path dependence (Gulati and Gargiulo, 
1999; Watts, 1999). Scholars have devoted considerable efforts to highlighting these network embeddedness effects given their prevalence and importance (Carpenter et al., 2012).

Notably, with few exceptions (Lomi and Pattison, 2006; Shipilov and Li, 2012), prior network research has examined an actor's embeddedness in a single network without specifically differentiating social ties and networks formed through different activities. However, scholars have long recognized that organizational actors may play multiple roles and engage in various activities, thus simultaneously participating in different types of relationships and networks (Gould, 1991; Provan et al., 2007). Given the potentially different natures of interaction and exchange patterns, network compositions, and structural features, these parallel networks tend to concurrently exert heterogeneous embeddedness influences, which may interplay in shaping the focal actor's decisions and actions. For instance, Jiang and colleagues (2017) show that senior executives’ professional networks with external stakeholders and personal connections with peers in their firms, which have distinct functions and involve different contacts, can shape the voluntary turnover decisions of executives in different ways. Such heterogeneous embeddedness effects cannot be effectively unveiled without distinguishing different types of networks.

We highlight the value of expanding the network embeddedness perspective with a network pluralism approach by resolving an embeddedness-related dilemma about the addition of new alliance partners. That is, as discussed above, the embeddedness constraints exerted by a firm's ongoing alliance network will both encourage the firm to add new partners to offset such constraints and impede it from doing so. By differentiating two activity-based alliance networks (i.e., exploratory and exploitative networks), we found the non-monotonic within-network effect and the monotonic cross-network effect between network constraints and the addition of new alliance partners. As such, our findings show the necessity and value of highlighting the coexistence between the network embeddedness effects from multiple sources by extending the 
network pluralism approach, which emphasizes the coexistence of multiple networks defined by different activities (Laumann, 1973; Shipilov et al., 2014). As such, we contribute to the network literature by introducing a new way to examine network embeddedness and constraints.

\section{Implications for alliance research}

We contribute to the alliance network and alliance portfolio literatures in the following ways. First, by separating firms’ alliances into two distinct networks based on their basic alliance activities (i.e., exploration and exploitation), we highlight the difference between the within- and between-network effects of network cohesion on new partner addition. The findings indicate that firms may not manage their alliance portfolios as single ego-centric networks, but rather have distinct networking efforts and associated strategies for alliances involving different activities. As such, our findings show that it is necessary and valuable for future alliance research to highlight the heterogeneity across different alliances when examining firms’ networking practices and the evolution of alliance networks (Carpenter et al., 2012; Provan et al., 2007).

Second, in his seminal work, Uzzi (1997) showed the inverted U-shaped relationship between a firm's embeddedness in the interfirm network and its performance, pointing out that interfirm networks with medium levels of embeddedness would have optimal effects. However, little is known about how firms can achieve optimal levels of embeddedness in their alliance networks. By unveiling the ways in which firms can manage the embeddedness constraints across their exploratory and exploitative networks, our network pluralism approach provides a possible solution for firms to construct their alliances to optimize the overall embeddedness levels in their multiple alliance networks. As such, our study and findings complement and expand the existing understanding about embeddedness in two types of alliance networks, advancing the application of the network embeddedness perspective in alliance network research. 
We also advance the application of the exploration-exploitation categorization in alliance research (e.g., Gay and Dousset, 2005; Gilsing and Nooteboom, 2005; Koza and Lewin, 1999; Rothaermel and Deeds, 2004). That is, our findings show the different evolutionary patterns of exploratory and exploitative networks, as well as the co-evolution between these two activitybased networks, shedding light on the ways in which firms can balance their exploratory and exploitative activities in interfirm cooperation in terms of their alliance portfolios.

\section{Practical implications}

Our study provides useful practical implications for firms' alliance practices. Our findings show that when a firm is deeply entrenched in its cohesive ongoing alliance network and has little structural autonomy to offset the high embeddedness constraints in an existing alliance network conducting a certain type of activities, it may still be able to escape from this highly cohesive alliance network by seeking new partners conducting other activities. Therefore, our study provides a new and useful perspective for firms, especially those that are overly embedded in their alliance networks, to manage their network constraints.

Our study also has implications for alliance partner selection. According to our findings, firms with cohesive alliance networks tend to be motivated to search for new partners. However, they are more likely to add new partners outside the currently constrained activity-based network. Following this logic, a firm can advance successful formation of new alliances by focusing more on highly constrained firms with complementary activities.

\section{Limitations and future extensions}

Our study has limitations on which future research can build to further develop this topic. Drawing on the network pluralism approach to explore the addition of new alliance partners, we mainly emphasized the difference between two activity-based alliance networks (exploratory and exploitative). Nonetheless, prior network research has highlighted the intersections of multiple 
forms of networks within the interfirm context (political networks, family networks, alumni networks, etc.) and their implications for the evolution of interfirm networks and business communities (e.g., Padgett and Ansell, 1993; Siegel, 2007). Future studies can further examine these heterogeneous interfirm networks and investigate their interplay. For example, we mainly focused on the embeddedness constraints from interfirm alliances. However, the executives and directors in partner firms can also develop interpersonal ties with each other over time. These interpersonal ties may also play important roles in firms’ decisions about adding new partners. Accordingly, future research can benefit from highlighting the interplay between a firm’s embeddedness constraints from its managerial personal networks and alliance networks.

Moreover, we draw on the network pluralism approach to advance the application of the network embeddedness perspective in explaining firms’ alliance formation with new partners. However, other theories also provide useful insights to enrich our understanding about network embeddedness. Future research can thus benefit from embracing other theoretical perspectives to enrich network embeddedness research. For example, as discussed above, structural path dependence is a central source of embeddedness constraints from alliance networks (Borgatti and Cross, 2003; Carpenter et al., 2012). Such structural path dependence in alliance networks may echo and interplay with the established routines and path dependence within the focal firms. In this regard, bridging across routine theory (Cohen, 1991) and network embeddedness perspectives may inspire fresh views for both network theory and alliance research.

In addition, following prior studies (e.g., Ahuja, 2000; Burt, 1992), we mainly explore the implications of network cohesion as a key indicator of embeddedness in alliance networks. Future research may benefit from highlighting the structure of alliance networks in more detailed ways. For example, a firm’s alliance network may be consisting of few tightly connected cliques and numerous peripheral partners beyond those cliques (Carpenter et al., 2012). In this regard, 
the focal firm would have distinct mechanisms and patterns for adding new alliance partners into those cliques and adding new loosely connected peripheral partners. Moreover, compared to the alliance network with imbalanced distribution of connections, firms embedded in alliance networks with equally dense connections among all partners may also have different ways to add new alliance partners. In such a manner, examining the implications of such detailed structural features for alliance partner addition may provide novel and intriguing insights to further advance our findings.

\section{Conclusion}

In this study, we address a theoretical dilemma regarding how alliance network constraint shapes a firm's effort to add new partners. Using a network pluralism approach, we separate a firm's alliances into an exploratory network and an exploitative network based on the primary value chain activities involved in each alliance. We find evidence that the cohesion of an activity-based network has an inverted U-shaped effect on the addition of new partners in the same network, and a positive effect on the addition of new partners in the other network. Our findings both contribute to the extant alliance network research and advance the network embeddedness perspective, which may inspire future research in this field. 


\section{REFERENCES}

Adegbesan JA, Higgins MJ. 2011. The intra-alliance division of value created through collaboration. Strategic Management Journal 32(2): 187-211.

Ahuja G. 2000. Collaboration networks, structural holes, and innovation: A longitudinal study. Administrative Science Quarterly 45(3): 425-455.

Ahuja G. 2000. The duality of collaboration: Inducements and opportunities in the formation of interfirm linkages. Strategic Management Journal 21(3): 317-343.

Anand BN, Khanna T. 2000. Do firms learn to create value? The case of alliances. Strategic Management Journal 21(3): 295-315.

Argyres NS, Silverman BS. 2004. R\&D, organization structure, and the development of corporate technological knowledge. Strategic Management Journal 25(8-9): 929-958.

Bae J, Gargiulo M. 2004. Partner substitutability, alliance network structure, and firm profitability in the telecommunications industry. Academy of Management Journal 47(6): 843-859.

Baum JAC, Silverman BS. 2004. Picking winners or building them? Alliance, intellectual, and human capital as selection criteria in venture financing and performance of biotechnology startups. Journal of Business Venturing 19(3): 411-436.

Beckman CM, Burton MD. 2008. Founding the future: Path dependence in the evolution of top management teams from founding to IPO. Organization Science 19(1): 3-24.

Beckman CM, Haunschild PR, Phillips DJ. 2004. Friends or strangers? Firm-specific uncertainty, market uncertainty, and network partner selection. Organization Science 15(3): 259-275.

Benner MJ, Tushman ML. 2003. Exploitation, exploration, and process management: The productivity dilemma revisited. Academy of Management Review 28(2): 238-256.

Benson JK. 1975. The interorganizational network as a political economy. Administrative Science Quarterly 20(2): 229-249.

Blau PM. 1964. Exchange and power in social life. Wiley: New York.

Borgatti SP. 2010. Simple models for analyzing network change. In Research methods education for the global classroom. Detroit, MI.

Borgatti SP, Cross R. 2003. A relational view of information seeking and learning in social networks. Management Science 49(4): 432-445.

Borgatti SP, Foster PC. 2003. The network paradigm in organizational research: A review and typology. Journal of Management 29(6): 991-1013.

Burkhardt ME, Brass DJ. 1990. Changing patterns or patterns of change: The effects of a change in technology on social network structure and power. Administrative Science Quarterly 35(1): 104-127.

Burt RS. 1980. Cooptive corporate actor networks: A reconsideration of interlocking directorates involving American manufacturing. Administrative Science Quarterly 25: 557-582.

Burt RS. 1992. Structural holes: The social structure of competition. Harvard University Press: Cambridge, MA.

Burt RS. 1997. The contingent value of social capital. Administrative Science Quarterly 42(2): 339-365.

Burt RS. 2000. The network structure of social capital. In Research in organizational behavior. Staw BM, Sutton RI (eds.), JAI Press: Greenwich, CT.

Carpenter MA, Li M, Jiang H. 2012. Social network research in organizational contexts: A systematic review of methodological issues and choices. Journal of Management. 
Cohen MD. 1991. Individual learning and organizational routine: Emerging connections. Organization Science 2(1): 135-139.

Coleman JS. 1988. Social capital in the creation of human capital. American Journal of Sociology 94: S95-S120.

Connolly WE. 2005. Pluralism. Duke University Press: Durham, NC.

Das TK, Teng B-S. 1999. Managing risks in strategic alliances. Academy of Management Executive 13(4): 50-62.

Davis GF, Cobb AJ. 2010. Resource dependence theory: Past and future. In Stanford's organization theory renaissance, 1970-2000. Dobbin F, Schoonhoven CB (eds.), Emerald Group Publishing: Bingley, UK.

Doz YL, Olk PM, Ring PS. 2000. Formation processes of R\&D consortia: which path to take? Where does it lead? Strategic Management Journal 21(3): 239-266.

Emerson RM. 1962. Power-dependence relationships. American Sociological Review 27(1): 3141.

Ferriani S, Fonti F, Corrado R. 2015. The social and economic bases of network multiplexity: Exploring the emergence of multiplex ties. Strategic Organization 11(1): 7-34.

Gargiulo M. 1993. Two-step leverage: Managing constraint in organizational politics. Administrative Science Quarterly 38(1): 1-19.

Gargiulo M, Benassi M. 2000. Trapped in your own net? Network cohesion, structural holes, and the adaptation of social capital. Organization Science 11(2): 183-196.

Gay B, Dousset B. 2005. Innovation and network structural dynamics: Study of the alliance network of a major sector of the biotechnology industry. Research Policy 34(10): 14571475.

Gilsing VA, Nooteboom B. 2005. Density and strength of ties in innovation networks, an analysis of multimedia and biotechnology. European Management Review 2(3): 179-197.

Gimeno J. 2004. Competition within and between networks: The contingent effect of competitive embeddedness on alliance formation. Academy of Management Journal 47(6): 820-842.

Gnyawali DR, Madhavan R. 2001. Cooperative networks and competitive dynamics: A structural embeddedness perspective Academy of Management Review 26(3): 431-445.

Gould RV. 1991. Multiple networks and mobilization in the Paris commune, 1871. American Sociological Review 56(6): 716-729.

Granovetter M. 1973. The strength of weak ties. American Journal of Sociology 78(6): 13601380.

Granovetter M. 1985. Economic action and social structure: The problem of embeddedness. American Journal of Sociology 91: 481-510.

Gulati R. 1995. Does familiarity breed trust? The implications of repeated ties for contractual choices in alliances. Academy of Management Journal 38(1): 85-112.

Gulati R. 1999. Network location and learning: The influence of network resources and firm capabilities on alliance formation. Strategic Management Journal 20(5): 397-420.

Gulati R. 2007. Managing network resources: Alliances, affiliations, and other relational assets. Oxford University Press: Oxford, UK.

Gulati R, Gargiulo M. 1999. Where do interorganizational networks come from? American Journal of Sociology 104(5): 1439-1493.

Gulati R, Westphal JD. 1999. Cooperative or controlling? The effects of CEO-board relations and the content of interlocks on the formation of joint ventures. Administrative Science Quarterly 44(3): 473-506. 
Gupta AK, Smith KG, Shalley CE. 2006. The interplay between exploration and exploitation. Academy of Management Journal 49(4): 693-706.

Hagedoorn J. 1993. Understanding the rationale of strategic technology partnering: Interorganizational modes of cooperation and sectoral differences. Strategic Management Journal 14(5): 371-385.

Halinen A, Jan-Åke. T. 2005. Using case methods in the study of contemporary business networks. Journal of Business Research 58(9): 1285-1297.

Hart P, Saunders C. 1997. Power and trust: Critical factors in the adoption and use of electronic data interchange. Organization Science 8(1): 23-42.

Hill CWL, Rothaermel FT. 2003. The performance of incumbent firms in the face of radical technological innovation. Academy of Management Review 28(2): 257-274.

Hillman AJ, Withers MC, Collins BJ. 2009. Resource dependence theory: A review. Journal of Management 35(6): 1404-1427.

Hoehn-Weiss MN, Karim S. 2013. Unpacking functional alliance portfolios: How signals of viability affect young firms' outcomes. Strategic Management Journal: n/a-n/a.

Hoetker G, Mellewigt T. 2009. Choice and performance of governance mechanisms: matching alliance governance to asset type. Strategic Management Journal 30(10): 1025-1044.

Hoffmann WH. 2007. Strategies for managing a portfolio of alliances. Strategic Management Journal 28(8): 827-856.

Hsu DH. 2004. What do entrepreneurs pay for venture capital affiliation? Journal of Finance 59(4): 1805-1844.

Jiang H, Cannella AA, Jr., Xia J, Semadeni M. 2017. Choose to fight or choose to flee? A network embeddedness perspective of executive ship jumping in declining firms. Strategic Management Journal: n/a-n/a.

Kim H, Hoskisson RE, Wan WP. 2004. Power dependence, diversification strategy, and performance in keiretsu member firms. Strategic Management Journal 25(7): 613-636.

Kogut B, Shan W, Walker G. 1992. The make-or-cooperate decision in the context of an industry network. In Networks and Organizations: Structure, Form, and Action. Nohria N, Eccles RG (eds.), Harvard Business School Press: Boston MA.

Koza MP, Lewin A. 1999. The coevolution of network alliances: A longitudinal analysis of an international professional service network. Organization Science 10(5): 638-653.

Koza MP, Lewin AY. 1998. The co-evolution of strategic alliances. Organization Science 9(3): 255-264.

Lambert DM, Cooper MC. 2000. Issues in supply chain management. Industrial Marketing Management 29(1): 65-83.

Laumann EO. 1973. Bonds of pluralism: The form and substance of urban social networks. Wiley-Interscience: New York.

Laumann EO, Galaskiewicz J, Marsden PV. 1978. Community structure as interorganizational linkages. Annual Review of Sociology 4: 455-494.

Laumann EO, Marsden PV, Prensky D. 1989. The boundary specification problem in network analysis. In Research methods in social network analysis. Freeman LC, White DR, Romney AK (eds.), Transaction Publishers: New Brunswick.

Lavie D. 2006. The competitive advantage of interconnected firms: An extension of the resource-based view. Academy of Management Review 31(3): 638-658. 
Lavie D, Kang J, Rosenkopf L. 2009. The performance effects of balancing exploration and exploitation within and across alliance domains. Academy of Management Proceedings August: 1-6.

Lavie D, Rosenkopf L. 2006. Balancing exploration and exploitation in alliance formation. Academy of Management Journal 49(4): 797-818.

Lin ZJ, Yang H, Demirkan I. 2007. The performance consequences of ambidexterity in strategic alliance formations: Empirical investigation and computational theorizing. Management Science 53(10): 1645-1658.

Lomi A, Pattison P. 2006. Manufacturing relations: An empirical study of the organization of production across multiple networks. Organization Science 17(3): 313-332.

McFadyen MA, Cannella AA, Jr. 2010. Dynamic networks and knowledge creation. Paper presented at the Academy of Management Annual Meetings, Montreal, Canada.

McFadyen MA, Cannella AA, Jr. 2016. The dynamics of ego networks for knowledge workers. Journal of Management 42(4): 1005-1029.

Mizruchi MS. 1993. Cohesion, equivalence, and similarity of behavior: a theoretical and empirical assessment. Social Networks 15(3): 275-307.

Padgett JF, Ansell CK. 1993. Robust action and the rise of the Medici, 1400-1434. American Journal of Sociology 98(6): 1259-1319.

Pfeffer J, Salancik GR. 1978. The external control of organizations: A resource dependence perspective. Harper \& Row: New York.

Powell GN. 1998. Reinforcing and extending today's organizations: The simultaneous pursuit of person-organization fit and diversity. Organizational Dynamics 26(3): 50-61.

Powell WW, Koput KW, Smith-Doerr L. 1996. Interorganizational collaboration and the locus of innovation: Networks of learning in biotechnology. Administrative Science Quarterly 41(1): 116-145.

Provan KG. 1980. Board power and organizational effectiveness among human service agencies. Academy of Management Journal 23: 221-236.

Provan KG, Fish A, Sydow J. 2007. Interorganizational networks at the network level: A review of the empirical literature on whole networks. Journal of Management 33(3): 479-516.

Reagans R, McEvily B. 2003. Network structure and knowledge transfer: The effects of cohesion and range. Administrative Science Quarterly 48(2): 240-267.

Reagans R, Zuckerman E, McEvily B. 2004. How to make the team: Social networks vs. demography as criteria for designing effective teams. Administrative Science Quarterly 49(1): 101-133.

Reuer JJ, Ariño A. 2007. Strategic alliance contracts: Dimensions and determinants of contractual complexity. Strategic Management Journal 28(3): 313-330.

Reuer JJ, Zollo M. 2005. Termination outcomes of research alliances. Research Policy 34(1): 101-115.

Rothaermel FT. 2001. Complementary assets, strategic alliances, and the incumbent's advantage: An empirical study of industry and firm effects in the biopharmaceutical industry. Research Policy 30(8): 1235-1251.

Rothaermel FT. 2001. Incumbent's advantage through exploiting complementary assets via interfirm cooperation. Strategic Management Journal 22(6-7): 687-699.

Rothaermel FT, Alexandre MT. 2009. Ambidexterity in technology sourcing: The moderating role of absorptive capacity. Organization Science 20(4): 759-780. 
Rothaermel FT, Boeker W. 2008. Old technology meets new technology: complementarities, similarities, and alliance formation. Strategic Management Journal 29(1): 47-77.

Rothaermel FT, Deeds DL. 2004. Exploration and exploitation alliances in biotechnology: A system of new product development. Strategic Management Journal 25(3): 201-221.

Rowley TJ, Greve HR, Rao H, Baum JAC, Shipilov AV. 2005. Time to break up: Social and instrumental antecedents of firm exits from exchange cliques. Academy of Management Journal 48(3): 499-520.

Ruekert RW, Walker OC. 1987. Marketing's ilnteraction with other functional units: A conceptual framework and empirical evidence. Journal of Marketing 51(1): 1-19.

Rushton A, Croucher P, Baker P. 2014. The handbook of logistics and distribution management: Understanding the supply chain. Kogan Page Publishers: London.

Sampson RC. 2007. R\&D alliances and firm performance: The impact of technological diversity and alliance organization on innovation. Academy of Management Journal 50(2): 364386.

Saxton T. 1997. The effects of partner and relationship characteristics on alliance outcomes. Academy of Management lournal 40(2): 443-461.

Schilling MA, Phelps CC. 2007. Interfirm collaboration networks: The impact of large-scale network structure on firm innovation. Management Science 53(7): 1113-1126.

Scott J. 2000. Social network analysis: A handbook. Sage: Thousand Oaks, CA.

Shan W, Walker G, Kogut B. 1994. Interfirm cooperation and startup innovation in the biotechnology industry. Strategic Management Journal 15(5): 387-394.

Shipilov A, Gulati R, Kilduff M, Li S, Tsai W. 2014. Relational pluralism within and between organizations. Academy of Management Journal 57(2): 449-459.

Shipilov AV, Li SX. 2012. The missing link: The effect of customers on the formation of relationships among producers in the multiplex triads. Organization Science 23(2): 472491.

Siegel J. 2007. Contingent political capital and international alliances: Evidence from South Korea. Administrative Science Quarterly 52(4): 621-666.

Simcoe TS. 2007. XTPQML: Stata module to estimate fixed-effects Poisson quasi-ml regression with robust standard errors. Boston College Department of Economics: Boston.

Snijders TAB, van de Bunt GG, Steglich CEG. 2010. Introduction to actor-based models for network dynamics. Social Networks 32(1): 44-60.

Sørensen JB, Stuart TE. 2000. Aging, obsolescence, and organizational innovation. Administrative Science Quarterly 45(1): 81.

Sorenson O, Stuart TE. 2008. Bringing the context back in: Settings and the search for syndicate partners in venture capital investment networks Administrative Science Quarterly 53(2): 266-294.

Stuart TE. 2000. Interorganizational alliances and the performance of firms: A study of growth and innovation rates in a high-technology industry. Strategic Management Journal 21(8): 791-811.

Tiwana A. 2008. Does interfirm modularity complement ignorance? A field study of software outsourcing alliances. Strategic Management Journal 29(11): 1241-1252.

Toegel G, Kilduff M, Anand N. 2013. Emotion helping by managers: An emergent understanding of discrepant role expectations and outcomes. Academy of Management Journal 56(2): 334-357. 
Tsai W. 2001. Knowledge transfer in intraorganizational networks: Effects of network position and absorptive capacity on business unit innovation and performance. Academy of Management Journal 44(5): 996-1004.

Tushman ML, O'Reilly CA, III. 1996. Ambidextrous organizations: Managing evolutionary and revolutionary change. California Management Review 38(4): 8-30.

Uzzi B. 1997. Social structure and competition in interfirm networks: The paradox of embeddedness. Administrative Science Quarterly 42(1): 35-67.

Walker G, Kogut B, Shan W. 1997. Social capital, structural holes and the formation of an industry network. Organization Science 8(2): 109-125.

Wasserman S, Faust K. 1994. Social network analysis: Methods and applications. Cambridge University Press: New York.

Wassmer U. 2010. Alliance portfolios: A review and research agenda. Journal of Management 36(1): 141-171.

Watts DJ. 1999. Networks, dynamics, and the small-world phenomenon. American Journal of Sociology 105(2): 493-527.

Wooldridge JM. 1999. Distribution-free estimation of some nonlinear panel data. Journal of Econometrics 90(1): 77-97.

Xia J. 2011. Mutual dependence, partner substitutability, and repeated partnership: the survival of cross-border alliances. Strategic Management Journal 32(3): 229-253.

Xin KR, Pearce JL. 1996. Guanxi: Connections as substitutes for formal institutional support. The Academy of Management Journal 39(6): 1641-1658.

Yan A, Gray B. 1994. Bargaining power, management control, and performance in United States-China joint ventures: A comparative case study. Academy of Management Journal 37(6): 1478-1517.

Yan A, Gray B. 2001. Antecedents and effects of parent control in international joint ventures. Journal of Management Studies 38(3): 393-416.

Yu J, Gilbert BA, Oviatt BM. 2011. Effects of alliances, time, and network cohesion on the initiation of foreign sales by new ventures. Strategic Management Journal 32(4): 424446.

Yu T, Subramaniam M, Cannella AA, Jr. 2013. Competing globally, allying locally: Alliances between global rivals and host country contextual factors. Journal of International Business Studies 44(2): 117-137.

Zaheer SA, Gözübüyük R, Milanov H. 2010. The network perspective in interorganizational research. Academy of Management Perspectives 24(1): 62-77.

Zaheer SA, Soda G. 2009. Network evolution: The origins of structural holes. Administrative Science Quarterly 54(1): 1-31.

Zajac EJ. 1988. Interlocking directorates as an interorganizational strategy: A test of critical assumptions. Academy of Management Journal 31(2): 428-438.

Zajac EJ, Olsen CP. 1993. From transaction cost to transactional value analysis: Implications for the study of interorganizational strategies. Journal of Management Studies 30(1): 131145. 
Table 1 Means, Standard Deviations, and Correlations

\begin{tabular}{|c|c|c|c|c|c|c|c|c|c|c|c|c|c|c|}
\hline & Mean & SD & 1 & 2 & 3 & 4 & 5 & 6 & 7 & 8 & 9 & 10 & 11 & 12 \\
\hline Adding new exploratory partners & 2.94 & 1.01 & - & & & & & & & & & & & \\
\hline Adding new exploitative partners & 2.62 & 1.07 & 0.08 & - & & & & & & & & & & \\
\hline Exploratory cohesion & 0.10 & 0.12 & 0.22 & 0.13 & - & & & & & & & & & \\
\hline Exploitative cohesion & 0.28 & 0.07 & -0.01 & 0.26 & 0.05 & - & & & & & & & & \\
\hline Exploitative degree centrality & 3.23 & 1.04 & 0.00 & 0.02 & 0.03 & -0.19 & - & & & & & & & \\
\hline Exploratory degree centrality & 2.21 & 1.59 & 0.04 & -0.04 & -0.02 & -0.24 & 0.01 & - & & & & & & \\
\hline ROA & 0.20 & 0.26 & 0.06 & 0.00 & -0.02 & 0.04 & -0.03 & -0.08 & - & & & & & \\
\hline Firm size & 143.25 & 468.19 & -0.01 & -0.02 & -0.01 & -0.11 & -0.03 & 0.04 & 0.04 & - & & & & \\
\hline Firm age & 5.03 & 3.59 & -0.04 & 0.04 & 0.06 & 0.04 & -0.01 & 0.00 & 0.03 & 0.00 & - & & & \\
\hline Technology diversity & 4.73 & 3.47 & -0.06 & 0.03 & 0.62 & 0.07 & 0.01 & -0.02 & -0.01 & 0.02 & 0.12 & - & & \\
\hline Exploration performance & 4.74 & 2.77 & 0.07 & 0.28 & 0.14 & -0.02 & -0.01 & 0.03 & 0.02 & -0.02 & -0.02 & 0.01 & - & \\
\hline Exploitation performance & 2.64 & 7.45 & 0.04 & 0.07 & 0.00 & -0.29 & 0.48 & 0.03 & 0.02 & 0.00 & 0.04 & -0.02 & -0.06 & - \\
\hline Number of acquisitions & 3.04 & 2.12 & -0.04 & 0.07 & 0.02 & 0.04 & -0.07 & 0.00 & -0.05 & -0.01 & -0.01 & 0.02 & -0.02 & -0.01 \\
\hline
\end{tabular}

* Unstandardized means and standard deviations are presented. Correlations represent standardized values. Correlations with absolute value of

0.06 and above are significant at the 0.05 level. $\mathrm{N}=1,025$ 
Table 2 Results for the Addition of New Exploratory Partners from $t$ to $t+1$

\begin{tabular}{|c|c|c|c|c|c|c|c|c|}
\hline & \multicolumn{2}{|c|}{ Model 1} & \multicolumn{2}{|c|}{ Model 2} & \multicolumn{2}{|c|}{ Model 3} & \multicolumn{2}{|c|}{ Model 4} \\
\hline & $\mathrm{b}(\mathrm{SD})$ & $\mathrm{p}$-value & $\mathrm{b}(\mathrm{SD})$ & $\mathrm{p}$-value & $\mathrm{b}(\mathrm{SD})$ & $\mathrm{p}$-value & $\mathrm{b}(\mathrm{SD})$ & p-value \\
\hline Exploitative degree centrality & $\begin{array}{c}-3.73 \\
(2.71)\end{array}$ & 0.17 & $\begin{array}{c}-4.29 \\
(2.59)\end{array}$ & 0.10 & $\begin{array}{c}-3.6 \\
(2.72)\end{array}$ & 0.19 & $\begin{array}{c}-4.19 \\
(2.61)\end{array}$ & 0.11 \\
\hline Exploratory degree centrality & $\begin{array}{c}0.03 \\
(0.01)\end{array}$ & 0.02 & $\begin{array}{c}0.03 \\
(0.01)\end{array}$ & 0.00 & $\begin{array}{c}0.03 \\
(0.01)\end{array}$ & 0.02 & $\begin{array}{c}0.03 \\
(0.01)\end{array}$ & 0.01 \\
\hline ROA & $\begin{array}{c}0.07 \\
(0.06)\end{array}$ & 0.20 & $\begin{array}{c}0.05 \\
(0.05)\end{array}$ & 0.32 & $\begin{array}{c}0.06 \\
(0.06)\end{array}$ & 0.27 & $\begin{array}{c}0.05 \\
(0.06)\end{array}$ & 0.40 \\
\hline Firm size & $\begin{array}{l}-0.03 \\
(0.14)\end{array}$ & 0.81 & $\begin{array}{c}0.00 \\
(0.13)\end{array}$ & 0.97 & $\begin{array}{l}-0.04 \\
(0.14)\end{array}$ & 0.80 & $\begin{array}{l}-0.01 \\
(0.13)\end{array}$ & 0.94 \\
\hline Firm age & $\begin{array}{c}-0.01 \\
(0.04)\end{array}$ & 0.74 & $\begin{array}{c}-0.01 \\
(0.04)\end{array}$ & 0.76 & $\begin{array}{l}-0.01 \\
(0.04)\end{array}$ & 0.71 & $\begin{array}{l}-0.01 \\
(0.04)\end{array}$ & 0.75 \\
\hline Technology diversity & $\begin{array}{c}-0.04 \\
(0.04)\end{array}$ & 0.32 & $\begin{array}{c}-0.22 \\
(0.05)\end{array}$ & 0.00 & $\begin{array}{l}-0.04 \\
(0.05)\end{array}$ & 0.35 & $\begin{array}{l}-0.22 \\
(0.05)\end{array}$ & 0.00 \\
\hline Exploration performance & $\begin{array}{c}0.09 \\
(0.03)\end{array}$ & 0.01 & $\begin{array}{c}0.05 \\
(0.03)\end{array}$ & 0.10 & $\begin{array}{c}0.09 \\
(0.03)\end{array}$ & 0.00 & $\begin{array}{c}0.05 \\
(0.03)\end{array}$ & 0.09 \\
\hline Exploitation performance & $\begin{array}{c}0.41 \\
(0.33)\end{array}$ & 0.21 & $\begin{array}{c}0.46 \\
(0.32)\end{array}$ & 0.14 & $\begin{array}{c}0.48 \\
(0.33)\end{array}$ & 0.15 & $\begin{array}{c}0.50 \\
(0.32)\end{array}$ & 0.11 \\
\hline Number of acquisitions & $\begin{array}{c}-0.01 \\
(0.01)\end{array}$ & 0.06 & $\begin{array}{c}-0.01 \\
(0.01)\end{array}$ & 0.04 & $\begin{array}{l}-0.01 \\
(0.01)\end{array}$ & 0.05 & $\begin{array}{l}-0.01 \\
(0.01)\end{array}$ & 0.04 \\
\hline Exploratory cohesion & & & $\begin{array}{c}1.78 \\
(0.25)\end{array}$ & 0.00 & & & $\begin{array}{c}1.77 \\
(0.25)\end{array}$ & 0.00 \\
\hline Exploratory cohesion^2 & & & $\begin{array}{l}-3.10 \\
(0.83)\end{array}$ & 0.00 & & & $\begin{array}{c}-3.13 \\
(\mathbf{0 . 8 3}) \\
\end{array}$ & 0.00 \\
\hline Exploitative cohesion & & & & & $\begin{array}{c}1.49 \\
(1.21)\end{array}$ & 0.22 & $\begin{array}{c}1.19 \\
(1.27)\end{array}$ & 0.35 \\
\hline Exploitative cohesion^2 & & & & & $\begin{array}{l}-2.53 \\
(2.04)\end{array}$ & 0.21 & $\begin{array}{l}-2.10 \\
(2.13)\end{array}$ & 0.33 \\
\hline Wald Chi-square & \multicolumn{2}{|c|}{23.24} & \multicolumn{2}{|c|}{85.68} & \multicolumn{2}{|c|}{27.23} & \multicolumn{2}{|c|}{91.19} \\
\hline
\end{tabular}


Table 3 Results for the Addition of New Exploitative Partners from $t$ to $t+1$

\begin{tabular}{|c|c|c|c|c|c|c|c|c|}
\hline & \multicolumn{2}{|c|}{ Model 1} & \multicolumn{2}{|c|}{ Model 2} & \multicolumn{2}{|c|}{ Model 3} & \multicolumn{2}{|c|}{ Model 4} \\
\hline & b (SD) & $\mathrm{p}$-value & $\mathrm{b}(\mathrm{SD})$ & $\mathrm{p}$-value & $\mathrm{b}(\mathrm{SD})$ & $\mathrm{p}$-value & $\mathrm{b}(\mathrm{SD})$ & p-value \\
\hline Exploitative degree centrality & $\begin{array}{c}2.52 \\
(3.99)\end{array}$ & 0.53 & $\begin{array}{c}3.68 \\
(3.42)\end{array}$ & 0.28 & $\begin{array}{c}1.97 \\
(3.92)\end{array}$ & 0.62 & $\begin{array}{c}3.25 \\
(3.35)\end{array}$ & 0.33 \\
\hline Exploratory degree centrality & $\begin{array}{c}0.00 \\
(0.02)\end{array}$ & 0.93 & $\begin{array}{c}0.02 \\
(0.01)\end{array}$ & 0.13 & $\begin{array}{c}0.00 \\
(0.02)\end{array}$ & 0.98 & $\begin{array}{c}0.02 \\
(0.01)\end{array}$ & 0.11 \\
\hline ROA & $\begin{array}{l}-0.06 \\
(0.06)\end{array}$ & 0.36 & $\begin{array}{l}-0.11 \\
(0.06)\end{array}$ & 0.07 & $\begin{array}{l}-0.06 \\
(0.06)\end{array}$ & 0.33 & $\begin{array}{l}-0.11 \\
(0.06)\end{array}$ & 0.06 \\
\hline Firm size & $\begin{array}{c}0.06 \\
(0.16)\end{array}$ & 0.71 & $\begin{array}{c}0.27 \\
(0.16)\end{array}$ & 0.08 & $\begin{array}{c}0.06 \\
(0.16)\end{array}$ & 0.69 & $\begin{array}{c}0.27 \\
(0.16)\end{array}$ & 0.08 \\
\hline Firm age & $\begin{array}{c}0.12 \\
(0.04)\end{array}$ & 0.01 & $\begin{array}{c}0.08 \\
(0.04)\end{array}$ & 0.07 & $\begin{array}{c}0.12 \\
(0.04)\end{array}$ & 0.01 & $\begin{array}{c}0.08 \\
(0.04)\end{array}$ & 0.06 \\
\hline Technology diversity & $\begin{array}{c}0.01 \\
(0.05)\end{array}$ & 0.91 & $\begin{array}{c}0.00 \\
(0.05)\end{array}$ & 0.99 & $\begin{array}{l}-0.08 \\
(0.06)\end{array}$ & 0.21 & $\begin{array}{l}-0.06 \\
(0.06)\end{array}$ & 0.31 \\
\hline Exploration performance & $\begin{array}{c}0.22 \\
(0.03)\end{array}$ & 0.00 & $\begin{array}{c}0.24 \\
(0.03)\end{array}$ & 0.00 & $\begin{array}{c}0.20 \\
(0.03)\end{array}$ & 0.00 & $\begin{array}{c}0.22 \\
(0.03)\end{array}$ & 0.00 \\
\hline Exploitation performance & $\begin{array}{c}0.53 \\
(0.38)\end{array}$ & 0.16 & $\begin{array}{c}1.40 \\
(0.38)\end{array}$ & 0.00 & $\begin{array}{c}0.57 \\
(0.37)\end{array}$ & 0.12 & $\begin{array}{c}1.43 \\
(0.37)\end{array}$ & 0.00 \\
\hline Number of acquisitions & $\begin{array}{c}0.01 \\
(0.01)\end{array}$ & 0.19 & $\begin{array}{c}0.01 \\
(0.01)\end{array}$ & 0.37 & $\begin{array}{c}0.01 \\
(0.01)\end{array}$ & 0.23 & $\begin{array}{c}0.01 \\
(0.01)\end{array}$ & 0.42 \\
\hline Exploratory cohesion & & & & & $\begin{array}{c}0.56 \\
(0.30)\end{array}$ & 0.06 & $\begin{array}{c}0.56 \\
(0.28)\end{array}$ & 0.05 \\
\hline Exploratory cohesion^2 & & & & & $\begin{array}{c}-0.50 \\
(0.92) \\
\end{array}$ & 0.59 & $\begin{array}{c}-0.83 \\
(0.83) \\
\end{array}$ & 0.32 \\
\hline Exploitative cohesion & & & $\begin{array}{c}6.28 \\
(1.09)\end{array}$ & 0.00 & & & $\begin{array}{c}6.18 \\
(1.11)\end{array}$ & 0.00 \\
\hline Exploitative cohesion^2 & & & $\begin{array}{l}-7.11 \\
(1.66)\end{array}$ & 0.00 & & & $\begin{array}{l}-6.96 \\
(1.69)\end{array}$ & 0.00 \\
\hline Wald Chi-square & \multicolumn{2}{|c|}{57.36} & \multicolumn{2}{|c|}{157.15} & \multicolumn{2}{|c|}{60.64} & \multicolumn{2}{|c|}{163.85} \\
\hline
\end{tabular}


Table 4 Results of Sensitivity Analyses

\begin{tabular}{|c|c|c|c|c|c|c|c|c|}
\hline & \multicolumn{4}{|c|}{ Sensitivity Analysis 1} & \multicolumn{4}{|c|}{ Sensitivity Analysis 2} \\
\hline & \multicolumn{2}{|c|}{$\begin{array}{l}\text { DV: Adding new } \\
\text { exploratory partners }\end{array}$} & \multicolumn{2}{|c|}{$\begin{array}{l}\text { DV: Adding new } \\
\text { exploitative partners }\end{array}$} & \multicolumn{2}{|c|}{$\begin{array}{l}\text { DV: Adding new } \\
\text { exploratory partners }\end{array}$} & \multicolumn{2}{|c|}{$\begin{array}{l}\text { DV: Adding new } \\
\text { exploitative partners }\end{array}$} \\
\hline & $\mathrm{b}(\mathrm{SD})$ & p-value & $\mathrm{b}(\mathrm{SD})$ & p-value & $\mathrm{b}(\mathrm{SD})$ & $\mathrm{p}$-value & $\mathrm{b}(\mathrm{SD})$ & p-value \\
\hline Exploitative degree centrality & $\begin{array}{l}-2.80 \\
(3.04)\end{array}$ & 0.36 & $\begin{array}{c}4.72 \\
(4.52)\end{array}$ & 0.30 & $\begin{array}{l}-0.60 \\
(3.59)\end{array}$ & 0.87 & $\begin{array}{l}2.27 \\
(5.15)\end{array}$ & 0.66 \\
\hline Exploratory degree centrality & $\begin{array}{l}0.03 \\
(0.01)\end{array}$ & 0.02 & $\begin{array}{c}0.02 \\
(0.02)\end{array}$ & 0.25 & $\begin{array}{l}0.03 \\
(0.02)\end{array}$ & 0.08 & $\begin{array}{c}0.02 \\
(0.02)\end{array}$ & 0.34 \\
\hline ROA & $\begin{array}{l}0.08 \\
(0.07)\end{array}$ & 0.25 & $\begin{array}{l}-0.10 \\
(0.08)\end{array}$ & 0.20 & $\begin{array}{c}0.09 \\
(0.08)\end{array}$ & 0.26 & $\begin{array}{l}-0.11 \\
(0.09)\end{array}$ & 0.24 \\
\hline Firm size & $\begin{array}{l}0.07 \\
(0.15)\end{array}$ & 0.63 & $\begin{array}{c}0.25 \\
(0.20)\end{array}$ & 0.21 & $\begin{array}{l}0.02 \\
(0.21)\end{array}$ & 0.94 & $\begin{array}{l}0.26 \\
(0.24)\end{array}$ & 0.28 \\
\hline Firm age & $\begin{array}{l}-0.02 \\
(0.05)\end{array}$ & 0.60 & $\begin{array}{c}0.07 \\
(0.06)\end{array}$ & 0.21 & $\begin{array}{l}-0.02 \\
(0.06)\end{array}$ & 0.69 & $\begin{array}{c}0.12 \\
(0.06)\end{array}$ & 0.06 \\
\hline Technology diversity & $\begin{array}{l}-0.23 \\
(0.06)\end{array}$ & 0.00 & $\begin{array}{l}-0.06 \\
(0.08)\end{array}$ & 0.42 & $\begin{array}{l}-0.27 \\
(0.08)\end{array}$ & 0.00 & $\begin{array}{l}-0.10 \\
(0.09)\end{array}$ & 0.31 \\
\hline Exploration performance & $\begin{array}{c}0.06 \\
(0.04)\end{array}$ & 0.10 & $\begin{array}{c}0.25 \\
(0.04)\end{array}$ & 0.00 & $\begin{array}{c}0.04 \\
(0.04)\end{array}$ & 0.35 & $\begin{array}{c}0.30 \\
(0.05)\end{array}$ & 0.00 \\
\hline Exploitation performance & $\begin{array}{c}0.45 \\
(0.40)\end{array}$ & 0.26 & $\begin{array}{l}1.20 \\
(0.47)\end{array}$ & 0.01 & $\begin{array}{c}0.50 \\
(0.46)\end{array}$ & 0.28 & $\begin{array}{l}1.75 \\
(0.58)\end{array}$ & 0.00 \\
\hline Number of acquisitions & $\begin{array}{l}-0.01 \\
(0.01)\end{array}$ & 0.15 & $\begin{array}{c}0.01 \\
(0.01)\end{array}$ & 0.47 & $\begin{array}{l}-0.01 \\
(0.01)\end{array}$ & 0.18 & $\begin{array}{c}0.01 \\
(0.01)\end{array}$ & 0.27 \\
\hline Exploratory cohesion & $\begin{array}{l}1.87 \\
(0.26)\end{array}$ & 0.00 & $\begin{array}{l}1.20 \\
(0.33)\end{array}$ & 0.00 & $\begin{array}{l}1.60 \\
(0.26)\end{array}$ & 0.00 & $\begin{array}{c}0.54 \\
(0.32)\end{array}$ & 0.09 \\
\hline Exploratory cohesion^^2 & $\begin{array}{l}-3.56 \\
(0.94) \\
\end{array}$ & 0.00 & $\begin{array}{c}1.15 \\
(0.95) \\
\end{array}$ & 0.23 & $\begin{array}{l}-3.28 \\
(1.02) \\
\end{array}$ & 0.00 & $\begin{array}{l}-0.19 \\
(1.22) \\
\end{array}$ & 0.87 \\
\hline Exploitative cohesion & $\begin{array}{l}0.98 \\
(1.53)\end{array}$ & 0.52 & $\begin{array}{c}6.14 \\
(1.41)\end{array}$ & 0.00 & $\begin{array}{c}2.71 \\
(1.76)\end{array}$ & 0.12 & $\begin{array}{c}8.35 \\
(1.63)\end{array}$ & 0.00 \\
\hline Exploitative cohesion^2 & $\begin{array}{l}-1.94 \\
(2.68) \\
\end{array}$ & 0.47 & $\begin{array}{l}-6.62 \\
(2.20)\end{array}$ & 0.00 & $\begin{array}{l}-4.89 \\
(3.12)\end{array}$ & 0.12 & $\begin{array}{l}-10.05 \\
(2.49) \\
\end{array}$ & 0.00 \\
\hline Wald Chi-square & \multicolumn{2}{|c|}{78.89} & \multicolumn{2}{|c|}{206.50} & \multicolumn{2}{|c|}{61.20} & \multicolumn{2}{|c|}{118.68} \\
\hline
\end{tabular}

1. In Sensitivity Analysis 1, we recalculated the cohesions and the additions of new alliance partners in the exploratory network and the exploitative network by randomly assigning each ambidextarity alliance as either exploratory alliance or exploitative alliance.

2. In Sensitivity Analysis 2, we recalculated the cohesions and the additions of new alliance partners in the exploratory network and the exploitative network by removing all ambidextarity alliances from the whole network. 
Figure 1 Exploratory Network Cohesion and the Addition of Exploratory Partners

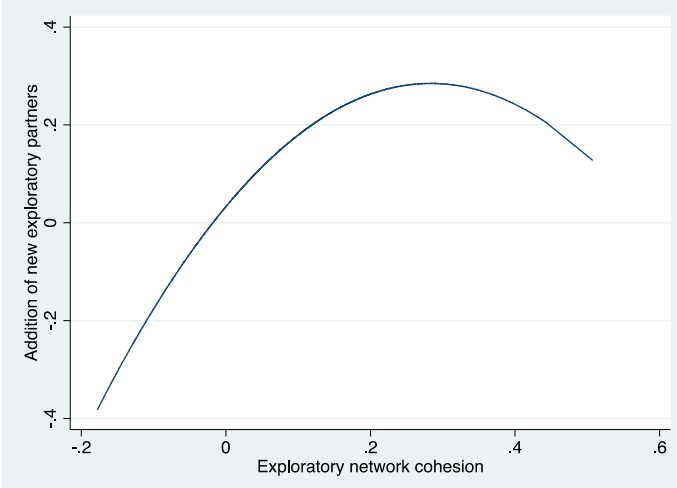

Figure 2 Exploitative Network Cohesion and the Addition of Exploitative Partners

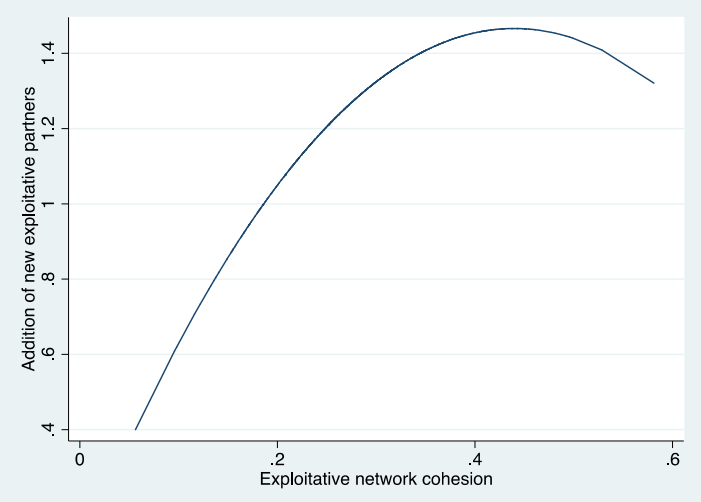

Figure 3 Exploratory Network Cohesion and the Addition of Exploitative Partners

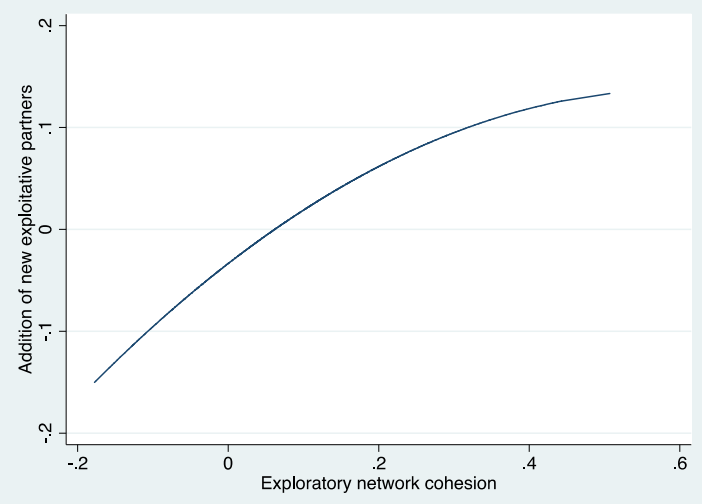




\section{Appendix 1 Two Alliance Networks in the Biotechnology Industry (1996-2000)}

\section{(1) Exploitative network}

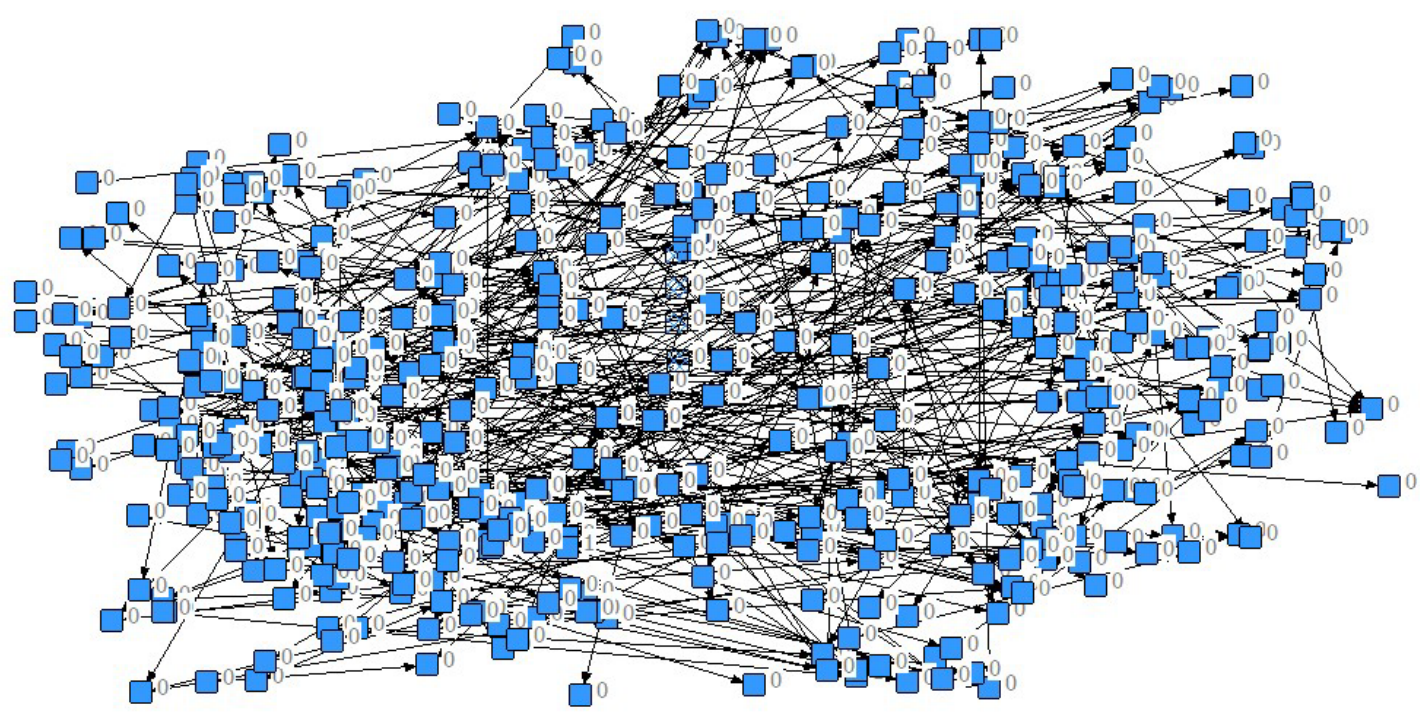

Note: Number of nodes $=350$, average tie strength $=2.47$, network density $=0.0105$

\section{(2) Exploratory network}



Note: Number of nodes $=310$, average tie strength $=1.03$, network density $=0.0046$ 